\title{
自動運転への過信・依存の評価を目的とした ドライバ状態の計测と解析
}

\section{荒川 俊也*}

\section{1. はじめに}

本論は，自動運転に対する過信・依存の評価を目的として, 生体情報に基づくドライバ状態の計測と解析について述べたも のである

現在，自動運転車の開発が各国で進められている。レオナル ド・ダ・ヴィンチが機械仕掛けの自動車を考えた時代から人類 は自動運転車を夢見てきたと言われている。古くは1939年に ゼネラル・モーターズが，ニューヨーク万国博覧会で「フュー チュラマ (Futurama)」と呼ばれる概念展示を行ったことがきっ かけとなり，自動運転のアイデイアが一般的に広まったと言わ れている $[1,2]$. その後, 様々な研究機関や大学などで自動運 転車が開発され，我が国においては 2008 年から 2012 年にか け，安全で環境にやさしい次世代の物流輸送システムの実現 を目指した大型トラックの隊列自動走行技術が開発されると 共に，2014 年度より政府が中心となり自動運転車の実用化を 目指した取り組み (SIP-adus（Automated Driving for Universal Service））が開始されている[3]. 現在は自動運転の早期実現 に向けて産学官が密接に連携した取り組みを推進しており，国 土交通省も，自動運転戦略本部の下，車両の安全確保等に関す るルール整備を実施している [4].

我が国を取り巻く環境を見てみると，少子高齢化や都市部の 人工集中をはじめとした社会構造の変化を背景に，道路交通を 巡る様々な社会的な課題の深刻化が懸念されている．例えば高 齢者が原因の交通事故割合の増加や，人口減少・過疎化が進む ことによる公共交通への需要減少や，それに伴う地方交通事業 者ならびに地方公共団体の財政逼迫，運転者不足などの複合的 な要因が相まって, 地域公共交通ネットワークの維持が一層困 難となり，交通空白地帯の拡大が懸念されている。そして，高 齢者をはじめとした移動弱者の移動手段確保が大きな課題とし て顕在化する恐れがある [5]

他方で，三大都市圈を中心とした都市部では，経済活動や人 口の更なる集中化やインバウンド需要の増加を背景として交通 渋滞や混雑が発生すれば，経済損失や地球温暖化等の要因にな

$\dagger \quad$ Measurement and Analysis of the Driver's State to Evaluate Overconfidence and Reliance on Autonomous Driving Toshiya ARAKAWA

* 愛知工科大学 工学部 機械システム工学科

Department of Mechanical Systems Engineering, Aichi University of Technology
表 1 自動運転のレベル

\begin{tabular}{|c|c|c|}
\hline \multirow{3}{*}{ ドライバによる監視 } & レベル 0 & 運転支援なし \\
\hline & レベル 1 & $\begin{array}{l}\text { 運転支援 } \\
\text { システムが前後・左右の } \\
\text { いずれかの車両制御を実施 }\end{array}$ \\
\hline & レベル 2 & $\begin{array}{l}\text { 特定条件下での運転支援機能 } \\
\text { （レベル } 1 \text { の組み合わせ） }\end{array}$ \\
\hline \multirow{3}{*}{ システムによる監視 } & レベル 3 & 条件付き自動運転 \\
\hline & レベル 4 & $\begin{array}{l}\text { 特定条件下における完全自動 } \\
\text { 運転 }\end{array}$ \\
\hline & レベル 5 & 完全自動運転 \\
\hline
\end{tabular}

ることが懸念されている [4]. 加えて，物流においては，eコ マースの更なる拡大等による物流需要の拡大が見込まれている 中，職業ドライバとして中高年層運転者に依存している現状， 物流の担い手不足も課題として挙げられている [5].

これらの問題を解決する手段としても自動運転への期待が高 まっている，さて，自動運転と十把一絡げに考えられている風 潮があるが, 実際には, 自動化されている機能によって段階毎 にレベルが存在する。レベル毎にどのような機能を備えている か, 表 1 にまとめた。なお，自動運転レベルの定義は，首相官 邸ホームページ「官民 ITS 構想・ロードマップ 2017」を参考に している [6]. 自動運転レベル 0 からレベル 2 までは, 安全運 転に係る監視や対応の主体がドライバであるが，レベル 3 から 5 までは，監視や対応の主体がシステムである，という点で大 きな違いがある。レベル 1 または 2 の運転自動化システム，も しくはレベル 3 の自動運転システムの性能が向上すればするほ ど，ドライバの運転機会が減少することによる運転技能の低下 だけでなく，システムに対する過信が生じることで，システム の機能失陥時にドライバが対応できない状況が起こり得る [7].

ドライバの負の適応には，システムに対する過信と依存があ ると言われている [8]. システムに対する過信については，「機 械を信頼してよい状況ではないにもかかわらず，そのことに気 が付かないまま下した『この機械は信頼できる』との誤った主 観的判断」であるという説明がある [9]. これを踏まえ, 自動 運転について考えると,「ドライバがシステムに対して過信し ている」と判断できる条件は，以下の 2 つが同時に起こる場合 という考えがある [7].

(1) ドライバがシステムを信頼している.

(2) システムが対応できない状況になっている. 
劉らは, ドライバがシステムの状態や機能の限界を理解でき る場合には，システムに対する信頼・不信を適切に判断できる ものとしている [7]. 一方, ドライバがシステムに対する正し い状況認識ができない場合には，過信（過剩信頼）と過剩不信 に陥りやすくなるとしている [7].

このように過信については概念が整理されつつある。その一 方で，システムに対する依存については，整理の途上であると 言えるため，様々な考えがあろう。そもそも依存とは，「特定 の物質や行為・過程に対して, やめたくても, やめられない, 程々にできない状態」であるとされる [10]. 一般的な機械や， 自動車の立場で考えると，「機械を用いて部分をこなしながら も，全体像が見えていない状態にある」状態や [11]，「システ ムの機能についてドライバが思考および行動の質を低下させる こと」とする見方 [12] がある，以上より，過信と依存は，どち らも，ドライバが自動運転のシステムを信頼しているというこ とは同じであろう。しかし，過信は，システムがドライバの要 求に対して対応できないか否か，ということであり，依存は， ドライバがシステムの全体像を把握していない（どこまで要求 できるか理解していない）ということである，という違いがあ ると考えられる。過信と依存の問題は，それらに起因する事故 が増えていることもあり [13], 近年重要な問題になっている. 自動運転に対する過信や依存に関する研究はこれまでにも行わ れてきているが $[14,15]$ 近年増加傾向にある印象である.

因みに，世間，特にマスコミは，自動運転レベル 1 から 5 を 区別せず，一律に「自動運転」と称している印象であるが，以 上の内容を考慮すると，これは極めて乱暴であり，重大な誤解 を招く．特に，自動運転レベル 1 および 2 が搭載されたシステ ムを用いるにあたって，監視や対応がドライバ主体であるにも 拘らず，システム主体であると思い込み，過信や依存を招く危 険性がある。そのため，自動運転レベル 1 および 2 が搭載さ れたシステムは「運転支援」, レベル 3 から 5 が搭載されたシ ステムを「自動運転」と称し，誤解を招かないようにすべきで ある。

本論では，ドライバが自動運転に対する過信・依存に陥った 際の生体情報の特徴について，これまでに筆者らが実験および 検討した内容について述べる。本論で述べる実験は 2 つであ る。1つは，過信・依存を生じることに関する検証であり，も う 1 つは, 自動運転のシステムが破綻したことを想定した状況 下における，ドライバのメンタルワークロードや認知・判断に 関する検証である

本論の構成は次の通りである，第 2 節では，ドライバが自動 運転のシステムに対して過信・依存を生じることを検証する実 験について述べる，第 3 節では，自動運転のシステムが破綻， もしくはドライバにシステムから急遽権限移譲されたことを想 定した状況下に扔けるドライバ状態の評価実験について述べ る。第 4 節はまとめである。

\section{2. 過信・依存発生の検証}

\section{1 実験環境}

ドライバが，自動運転のシステムに対して，過信・依存を生 じる可能性を検証する実験を行った。実験は男子大学生 5 名

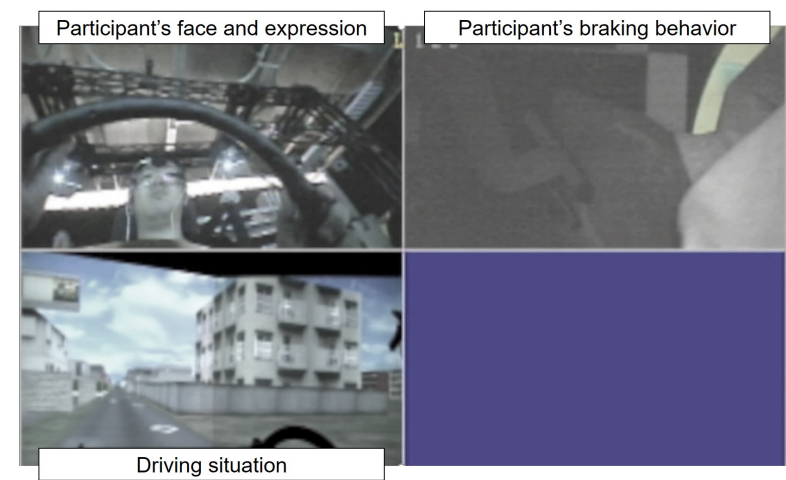

図 1 運転時の様子

（平均年齢 21 歳）に対して行った。それぞれの実験協力者はド ライビングシミュレータ（D3sim, 三菱プレシジョン製）に乗 り，市街地を模した環境を運転した。最初に自動運転レベル 0 を想定した状況（アクセル，ブレーキ，ステアリング操作全て 実験協力者自身で行い，自動車側が自動でこれらを制御するこ とは無い. 以降, MD (Manual Driving, マニュアル運転) と 称す.）で 15 分運転した。 その後休息を挟み, 次に, 自動運転 レベル 3 以上を想定した状況（車両の制御は全てシステム側 で行い，システムが主体となる運転。以降，AD (Autonomous Driving, 自動運転）と称す））で 15 分運転した。運転中は実験 協力者の視認行動を計測するため, 視線計測装置（T.K.K.2950 TalkEye Lite, 竹井機器工業株式会社製) を装着した状態で運転 した。また，運転中の実験協力者の顔画像を記録するために， ステアリング部にCMOS カメラ（YT-704， ワイケー無線株式 会社製）を装着した。加えて，実験協力者が，ブレーキペダル に足を乗せる，もしくはブレーキペダルを踏む行動（ブレーキ 挙動）を計測するために, 実験協力者の足元部に赤外線カメラ （YM-203C，ワイケー無線株式会社製）を装着した。実験時の 様子についてはビデオカメラ（Eberio，JVC 製）を用いて記録 した。これらの映像を画面分割切替器 (AQ-400, キャロット システムズ株式会社製）を用いて 1 画面とし，この画面を DV デッキ（GV-HD700，ソニー株式会社製）を用いて記録した。 運転時の様子を図 1 に示す。図 1 において, 左上は実験協力者 の表情，右上は実験協力者のブレーキ挙動，左下は運転時の状 況を示している。なお，全ての実験協力者に対し， $\mathrm{AD}$ 運転開 始前に,「自動運転のシステムは途中で作動しなくなる可能性 がある」という教示をしている，但し，実際には，作動しなく なることはない．

なお，本実験は，愛知工科大学ヒトを対象とする研究審査の 承認を得て実施している（承認番号：\#28-5).

\section{2 実験結果}

\subsection{1 視線停留割合について}

図 2 に, 実験協力者のうち, 1 名（実験協力者 A）の, 視線 停留割合の時系列変化を示す。(a) は MD，(b) は $\mathrm{AD} に$ におる 運転を示している。横軸は時間経過を, 縦軸は, 視線挙動の水 平方向成分を示している，縦軸について，0 [deg] は実験協力 者正面（自車進行方向）を示し, 負值は実験協力者から見て左 
(a)

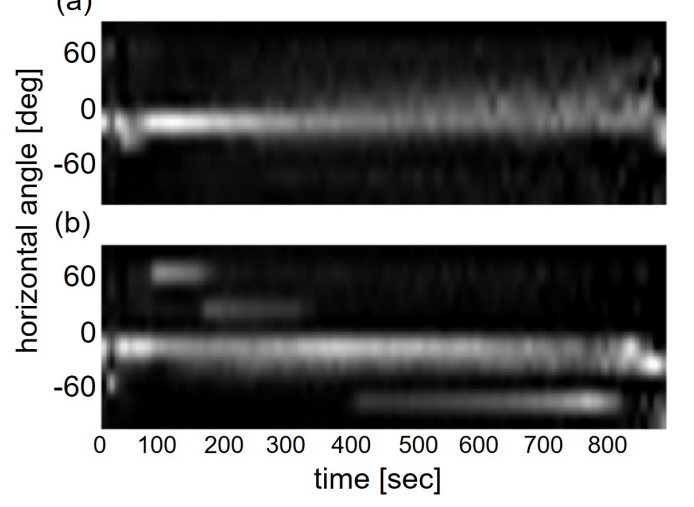

図2

実験協力者 $\mathrm{A}$ の運転時の視線停留割合の変化. (a): MD 時, (b): $\mathrm{AD}$ 時

方向，正值は実験協力者から見て右方向を示している．また， 色が白い箇所ほど，その時刻において，当該箇所を注視する割 合が高いことを意味している，逆に，色が黒い箇所ほど，当該 箇所を殆ど注視していないことを意味している.

図 2(a)より，MDのときは, 殆ど全ての時間で, 自車進行 方向を注視している。一方で, 図 2(b)より, $\mathrm{AD}$ のきは, 基 本的には自車進行方向を注視しているものの, 時折, 自車進行 方向とは異なる領域, 例えば $-60[\mathrm{deg}]$ 近傍や $+60[\mathrm{deg}]$ 近傍 を注視する場合が増えている，言い換えると，運転とは直接関 係の無い箇所を注視するようになっている，MDでは，自動運 転レベル 0 を想定していることもあり, 先行車に追突しないよ うにしたり，自車進行方向の障害物に対して注意を払っている

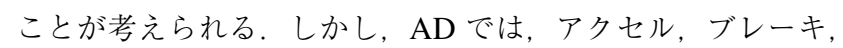
ステアリング操作を自ら行う必要もないこともあり，実験協 力者自身で周辺環境を認知・判断する必要がない. そのため, $-60[\mathrm{deg}]$ 近傍や $+60[\mathrm{deg}]$ 近傍といった運転に関係のない領 域を注視するようになっていると考えられる、筆者らの先行研 究 [16] では, 運転の合理化が進み, ドライバが漫然状態に遷移 した際に, 視線の水平方向成分のばらつきが大きくなり, 先行 者以外の領域を注視する傾向になることを示した．このことか ら考えると, ADにおける視線停留の状況は, 運転の合理化が 進んだことによる漫然化と類似した状態にあることが示唆され る. このような視線停留割合の推移は, 実験協力者 $\mathrm{A}$ 以外の 2 名についても同様であった。

\subsection{2 ブレーキ挙動について}

次に, 実験協力者の足元部を撮影した動画を基に, 運転開始 時から終了時まで, 実験協力者がブレーキ挙動をどの程度実施 したかを検証する。自動運転のシステムに対し過信・依存して いる場合は, ブレーキ挙動が殆ど生じず, 一方, システムに対 して過信・依存が発生していない場合は, ブレーキ挙動が頻繁 に発生するものと考えられる. 実験協力者 A のブレーキ挙動 の変化を図 3 に示す。 なお, 図 3 において, 薄い灰色の線は, $\mathrm{AD}$ によるブレーキを示し, 濃い灰色の線は, 実験協力者 $\mathrm{A} に$ よるブレーキを示す。薄い灰色の線と濃い灰色の線が完全に オーバーラップしていれば, ドライバは, 自動運転のシステム

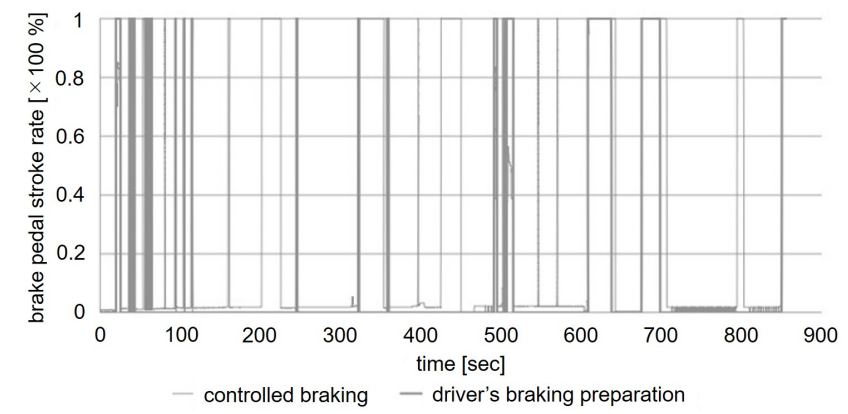

図 3 実験協力者 $\mathrm{A}$ の運転時のブレーキ挙動の変化

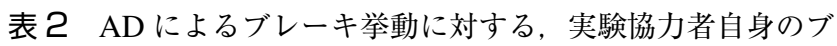
レーキ行動の割合

\begin{tabular}{cc}
\hline Participant No. & Braking rate [\%] \\
\hline A & 42.2 \\
B & 98.8 \\
C & 49.2 \\
D & 27.9 \\
E & 13.3 \\
\hline
\end{tabular}

を過信・依存しておらず，自らの判断を頼りにしてブレーキ挙 動を生じていると判断できる.

全ての実験協力者について，全運転時間における， $\mathrm{AD}$ 時の ブレーキ挙動に対する, 実験協力者自身のブレーキ行動の割合 を示したものを表 2 に示す. 実験協力者 B 以外の全ての実験 協力者は, $\mathrm{AD}$ 時のブレーキ挙動に対する, 実験協力者自身の ブレーキ挙動の割合が高々 $50 \%$ 程度であり, 多かれ少なかれ, 自動運転システムに対する過信・依存傾向が見られるものと示 唆される. 先行研究 [17] では, 自動運転中のドライバ行動に おいて, 先行者の減速・停止に対して, ブレーキペダルに足を 構えたドライバが約 $20 \%$ であるという知見が得られている. 本論の実験は, この先行研究のような, 先行者の減速・停止と いうシチュエイションではない.しかし, 自動運転システムに 対する過信・依存という観点では, 先行研究 [17] の結果の妥当 性を追認していると考えられる.

\subsection{3 覚醒度の推移について}

最後に, 実験協力者の顔画像を基に, $\mathrm{AD}$ 運転時における覚 醒度の推定を試みた。覚醒度推定にあたってはNEDOの評価 法を用いた [18]. NEDOの評価法とは, 実験協力者の顔画像 を数人で観測し, それぞれの顔画像が下記 (1) から (5) に示さ れた状態であれば当該の眠気レベルであるといういことを合議 制 (多数決) で判定するというものである.

(1) 眠気レベル 1: 全く眠くなさそう（視線の移動が早く頻繁 である。瞬きは 2 秒に 2 回くらいの安定した周期, 動きが 活発で身体の動きを伴う)

(2) 眠気レベル 2:やや眠そう（唇が開いている, 視線移動の 動きが遅い)

（3）眠気レベル 3：眠そう（瞬きはゆっくりと頻発，口の動き がある，座り直しあり，顔に手をやる）

（4）眠気レベル 4：かなり眠そう（意識的と思われる瞬きがあ 


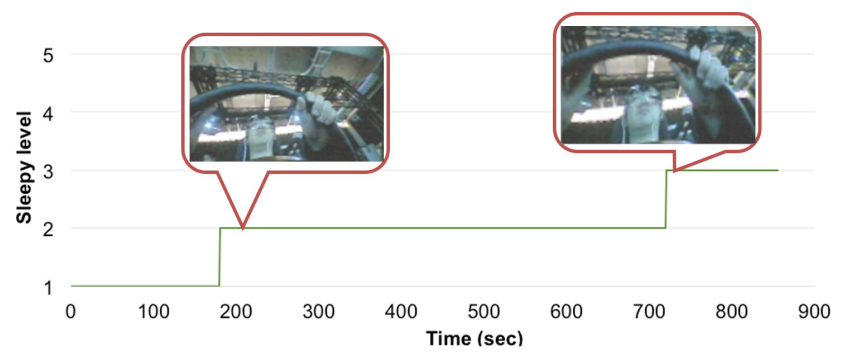

図 4 実験協力者 $\mathrm{A}$ の覚醒度の推移

る，頭を振る・肩の上下動などの無用な身体全体の動きが ある，あくびは頻発し深呼吸も見られる，瞬きも視線の動 きも遅い)

(5) 眠気レベル 5：非常に眠そう（瞼を閉じる，頭が前に傾く， 頭が後ろに倒れる)

NEDO の評価法の厳密なやり方としては， 5 秒毎に 5 段階の評 価点を付けるというものであり，2 名で行うことが推奨されて いる. 先行研究 [19]では, 評価において, 顔面表情や動作によ る眠気具合の変化点を捉えることが最も重要であるため, 明ら かに表情や動作の変化が起こった時間だけ評価点をつける方法 としており，本実験でもこの方法を採用した．実験協力者 $\mathrm{A} の$ 眠気レベルの推移を図 4 に示す. 図 4 より, 実験協力者 $\mathrm{A} の$ 眠気レベルは，運転開始時は眠気レベル 1 であったが，高々約 15 分の運転であっても, 運転終了時には, 眠気レベル 3 に上 昇していることがわかる，実際，実験協力者 $\mathrm{A}$ は，運転終了後 に，大あくびをして伸びをする，という行動が見受けられた。 このような覚醒度の推移は, 実験協力者 $\mathrm{A}$ 以外の 3 名につい ても同様であった，自動運転時の覚醒度の低下については，他 の先行研究 $[20,21]$ でも示されており, 本結果は妥当であると 示唆される.

\subsection{4 例外を示した実験協力者について}

これまでに示した，視線停留割合，ブレーキ挙動，覚醒度の 推移については， 5 名中 4 名, 同様の傾向を示している。 しか し, 実験協力者 B については, 他の実験協力者と異なる傾向を 示している，紙数の関係で図は省略するが，視線停留割合につ

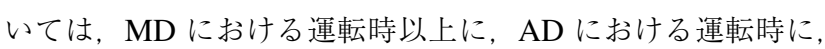
自車進行方向に視線が殆ど停留していた。ブレーキ挙動につい ては，表 2 より， $\mathrm{AD}$ によるブレーキ挙動に対する，実験協力 者 B 自身のブレーキ挙動の割合は, $98.8 \%$ であった。事後の質 問では,「ドライビングシミュレータによる運転であることは 知っているものの，自動運転システムを信頼できず，何かあっ たら先行車に追突するのではないかという気持ちがあり，過剩 に緊張していた，前方を注視し，自車進行方向に対して常に気 を配っていた。そのため，ブレーキペダルに，ほぼ常に足を乗 せていた」とのことであった。基本的には，自動運転システム に対する過信・依存は発生しやすいが，実験協力者 B の結果か ら，ドライバへの教示および教示に対するドライバの受け止め 方によっては，過信・依存を抑制できると示唆される.

\section{3. システム破綻時におけるドライバ状態評価}

自動運転レベル 3 では,「システムが全ての運転タスクを実 施するが，システムの介入要求等に対してドライバが適切に対 応することが必要」とされている [22]. すなわち, システムの 介入要求等があったときに, ドライバが要求に応えられるよう な状態にある必要がある。しかし, 覚醒度の低下や, 漫然など の状態下では，要求に適切に応えられるとは言えない．

さて，自動運転レベル 3 以上を実現するには，現在安全運転 支援システムで実用化されてる信頼性において大幅な技術革新 が求められている [3]. その一方で, 機械は, 予想外のときに 故障をすることがあれば, 突然壊れて使い物にならなくなって しまうこともあり，絶対に壊れない機械や設備を作ることは不 可能であるとされている [23]. 従って, ドライバがシステムの 介入要求を受ける事態は起こり得る話であり, 自動運転レベル 3 を実現するにあたっては，システムの介入要求を受ける際に, ドライバが, 介入要求に対応できるに相応しい状態である必要 がある。しかし，前節で述べたように，ドライバは，自動運転 システムに対して過信・依存する可能性が示唆されていること から，システムの介入要件に対応できない状態にある可能性が 考えられる.このことは, 過去に発生した, 自動運転システム における事故からも示唆されている。例えば，2018 年 3 月に， カリフォルニア州で発生した, 米国の電気自動車専門メーカー の車の自損事故の例が挙げられる [24]. この事故では, オート パイロット時に緊急事態が発生し, ドライバがハンドルを握 り，対応することを促す警報を出していたにも拘らず，ドライ バがそれに対応せず，衝突回避行動を行わなかったために発生 した。

ここでは， $\mathrm{MD}$ から $\mathrm{AD}, \mathrm{AD}$ から $\mathrm{MD}$ とシステムの状態が 遷移した際に，自動運転に対する過信・依存に起因して，ドラ イバが, システムの介入要件に対応できない状態になり得るこ とを検証する。

\section{1 実験環境}

実験は男性 13 名, 女性 1 名（21 歳〜46 歳）に対して行った. 実験協力者はドライビングシミュレータ（D3sim, 三菱プレシ ジョン製）に乗り，市街地を模した環境を運転した。運転は 3 週間実施し，1 週目は MD, 2 週目は $\mathrm{AD}, 3$ 週目は MD で運転 をした。 1 週毎に MD と AD を切り替えるという状況を設定 した理由は, シミュレータの仕様上, $\mathrm{MD}$ と $\mathrm{AD}$ それぞれの遷 移を，運転中に発生させることが不可能であるためである。な お， 3 週目の MD は，自動運転システムの破綻を想定したもの である. 2.1 節と同様に, MD は, 自動運転レベル 0 を想定し た状況であり， $\mathrm{AD}$ は，自動運転レベル 3 以上を想定した状況 とした。過去の調査結果を参照し [25], 各週の運転は平日の 3 日間実施した。従って, 実験協力者全員, 3 日 / 週 $\times 3$ 週 $=9$ 日 運転を行った。それぞれの実験協力者の各回の運転は, 同じ ルートとした。 また, サーカディアンリズムを考慮し [26], 各 実験協力者の運転開始時刻は全ての日で極力同じにするように した，各回の運転については，前節と同様に，MD および $\mathrm{AD}$ 共に約 15 分とした，全ての実験協力者は，運転中の視認行動 


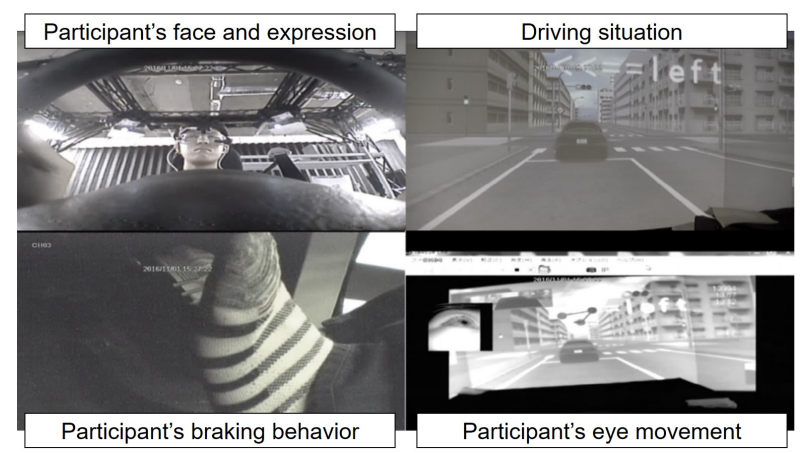

図 5 運転時の様子

を計測するため, 視線計測装置（T.K.K.2950 TallkEye Lite, 竹 井機器工業株式会社製)，実験協力者の運転時の血圧を計測す るため, 連続血圧計測装置（Radia press RBP-100, 株式会社 ケーアンドエス製)，および前頭部の酸素化へモグロビン濃度 （oxy-Hb）を計測するため, 携帯型脳活動計測装置（HOT-1000, $\mathrm{NeU}$ 株式会社製）を装着した。加えて，ドライバの座圧を調 ベるために，体圧検知センサ（SRソフトビジョン，住友理工 株式会社製）をシート座面に装着した。更に，運転前および運 転後，唾液アミラーゼモニ夕（CM-2.1，ニプロ株式会社製）を 用いて，唾液アミラーゼ濃度を計測した。唾液アミラーゼ濃度

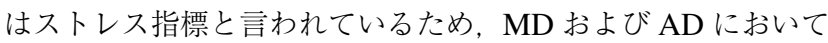
運転前後のストレスの増減を評価することが可能である。運転 時の様子を図 5 に示す。図 5 において，左上は実験協力者の表 情, 右上は運転時の状況, 左下は実験協力者のブレーキ挙動, 右下は実験協力者の視線挙動を示している.

なお，本実験は，愛知工科大学ヒトを対象とする研究審査の 承認を得て実施している（承認番号：\#28-5）.

\section{2 実験結果}

紙数の関係から, 血圧の結果と, 酸素化へモグロビン濃度の 結果についてのみ述べる。その他の計測結果についての詳細 は文献 [27] を参照されたい。なお，第 1 週目 1 日目から 3 日 目の MDをM1，M2 およびM3，第 2 週目 1 日目から 3 日目 の $\mathrm{AD}$ を $\mathrm{A} 1 ， \mathrm{~A} 2$ および $\mathrm{A} 3$ ，第 3 週目 1 日目から 3 日目の MDを M4，M5 および M6 と記す。また, 各実験協力者毎に, 10 [sec] 毎を 1 フレームと称し，フレーム単位でデータを算出 している.

\subsection{1 血圧について}

実験協力者 14 名の，M1 から M3， A1 から A3，および M4 から M6 に扮ける平均血圧を図 6 に示す。図 6 の上段は，M1 から M3 の変化を, 中段は, A1 から A3 の変化を, 下段は, M4 から M6 の変化を示している。ここで, 図 6 は, 運転開始 時の血圧からの相対的な変化を示しており，緊張やストレス等 によって，值が増加する，先行研究では，およそ 20 分の運転 で，血圧が 30 から $40[\mathrm{mmHg}]$ 上昇することが報告されてい る [28]. そのため, 図 6 における上昇傾向は, 自動車運転時の 自然な上昇であると考えることが妥当である.

A1 から A3 と，M1 から M3 を比較すると，前者の方が血
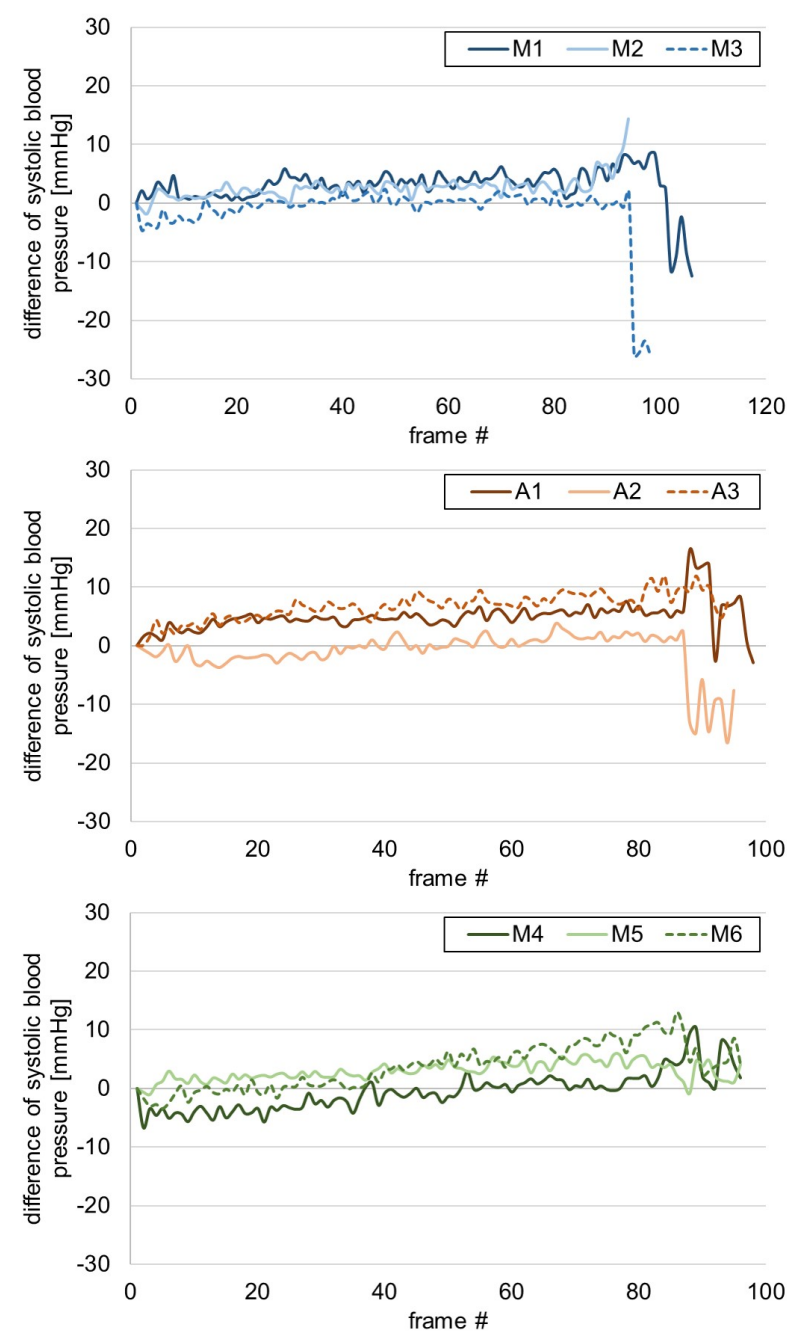

図 6 実験協力者 14 名の平均血圧の変化

圧の変化は後者よりも大きい傾向にある，これは，実験協力者 が， $\mathrm{AD} に よ っ て ，$ 自ら操縦せず，システム側でアクセル，ブ レーキ, ステアリング操作全て行うことに対する違和感を感じ ていることに起因すると考えられる. 加えて, 数名の実験協力

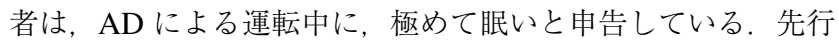
研究では, 眠気に抗うときに血圧が増加することが示唆されて いる [29]. 以上により，MDに比べて ADのほうが血圧が増加 しているものと考えられる。 しかし，本内容は，現時点におい て，あくまでも推測の域に過ぎない。次に，M4 から M6 と, M1 から M3 を比較すると, これらの血圧増加の傾向は類似し ているが，血圧の平均值は，M4 から M6 の方が， M1 から M3 の場合に比べて大きくなっている，M4，M5，M6 を比較する と, M4<M5<M6 と, 血圧が増加傾向にある.これは, A1 か ら A3 においては, 実験協力者のメンタルワークロードが MD 時に比べて低い一方， $\mathrm{AD}$ から MDに遷移した後に, 実験協力 者自身で認知・判断しなければならないという意識付けに基づ き,メンタルワークロードが増加したことに起因すると推測さ れる。

\subsection{2 前頭部酸素化へモグロビン濃度について}

左脳は論理的思考および判断を司ると言われている [30]. 本 

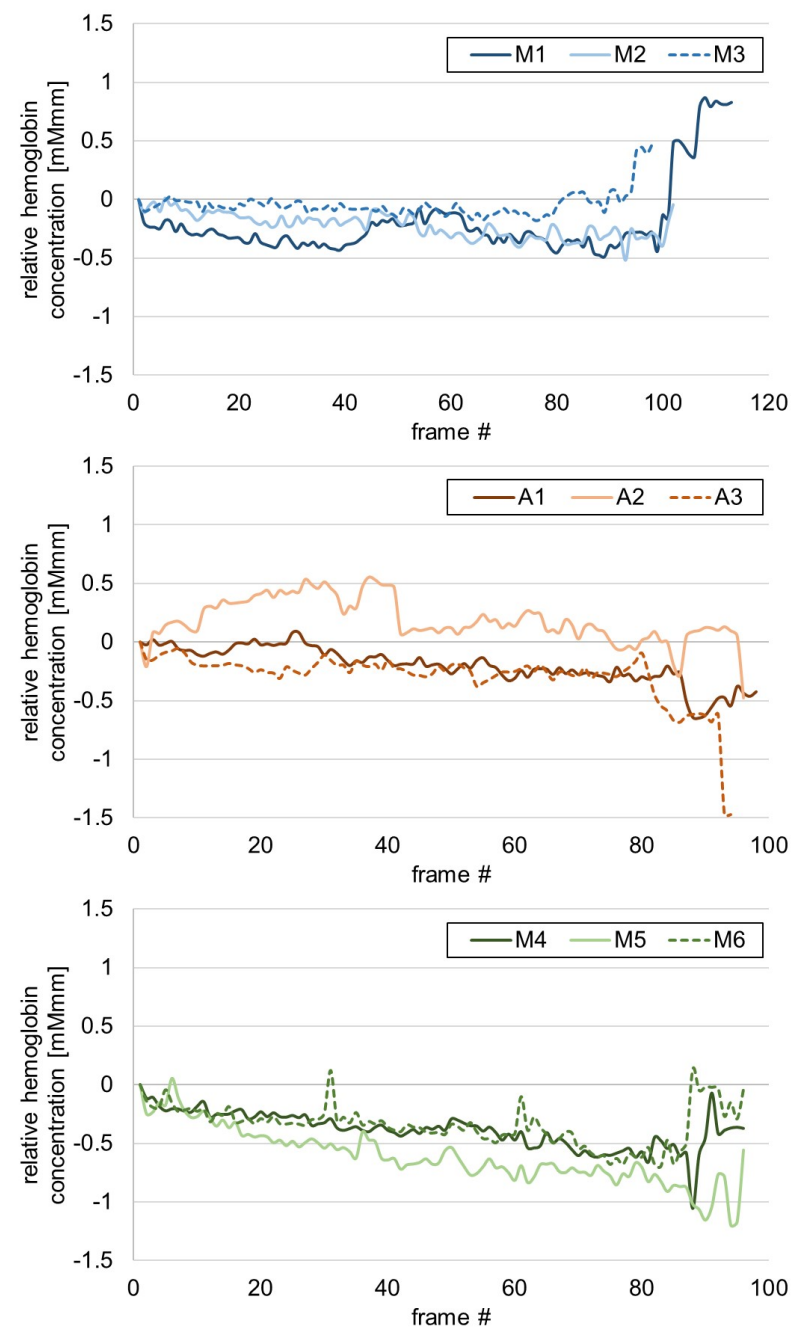

図 7 実験協力者 14 名の左前頭部の平均酸素化へモグロビン 濃度の変化

実験では，MD および AD における認知・判断について検証す るため, 左前頭部の平均酸素化へモグロビン濃度の変化を調べ た。実験協力者 14 名の, M1 から M3，A1 から A3，および M4 から M6における左前頭部酸素化へモグロビン濃度を図 7 に示す。図 7 の上段は, M1 から M3 の変化を, 中段は, A1 か ら A3 の変化を, 下段は, M4 から M6 の変化を示している. ここで，図 7 は，運転開始時の血圧からの相対的な変化を示し ており, 值が大きいほど, 実験協力者が, 論理的思考や判断を 行っていると解釈できる.

まず，M1 から M3 について考察する. 平均酸素化へモグロ ビン濃度は, M3 が最も高く, M1 が最も低い. MD において は，実験協力者が進むべきルートはスクリーン上に表示されナ ビゲートされるため（図 5 右上）, 実験において初回の運転で ある M1 では, 実験協力者は特にルートについて意識するこ となく, ナビゲーションに従って運転している。 しかし，M2， M3 と，運転を重ねるに従って，ナビゲーション表示を意識せ ずに，過去の運転で走行したルートを思い出しながら走行する ことに起因して，酸素化へモグロビン濃度が増加していると考 えられる．M2に比べて M3 の方が酸素化へモグロビン濃度が 増加しているのは，運転を重ねることにより，走行ルートを思
い出す頻度が増加しているためと推測される.

次に, A1 から A3 について考察する. A1 と A3 の平均酸素 化へモグロビン濃度は, MD 時と同等か, 低い值を取っている 傾向にある。このことは, A1 と A3 では, 実験協力者が, 運 転に対して意識を働かせていないことが示唆される。一方で, A2 の酸素化へモグロビン濃度の平均值は, A1 および A 3 に比 べると高い值を取っている。この理由は明確ではないが，実験 後に, 複数の実験協力者から, $\mathrm{AD}$ 時は運転が単調, 退屈であ るため, 運転とは関係のない他のことを考えていたというコメ ントがあった，従って，運転とは関係のない他のことを考えな がら運転をしていたということにより, 左前頭部の酸素化へモ グロビン濃度が増加しているものと思われる。但し，A3では $\mathrm{A} 2$ と同様の傾向にないことについては, 今後更に考察の必要 がある。

$\mathrm{AD}$ の後のシステム破綻を想定した MD，すなわち，M4 か ら M6 については，M1 から M3，および，A1 から A3 に比べ て, 酸素化へモグロビン濃度が減少する傾向が著しい，ADで は，実験協力者は，センサに頼って運転すれば良いこともあり， 基本的に, 周辺環境に注意を払う必要がない. しかし, システ ム破綻を想定した MDでは, 実験協力者は, $\mathrm{AD}$ を経験した後 ということを鑑みると, 周辺環境を見てはいるものの, M1 か ら M3 と同等の認知・判断度合いで周辺環境を認知・判断して いない可能性が考えられる。いわば，「意識の脇見」[31]と似 たような状態にあることが考えられる。一方で, 3.2 .1 節の考 察に従うと, ドライバは, 自分で認知・判断しなければならな いという意識を持っていると考えられる，そのため，意識と実 際が乘離している状況である可能性が示唆される。このことか ら, システムからの介入要求があり, $\mathrm{AD}$ から MD に遷移した 際には，周辺環境を認知・判断しなければならない意識はあっ ても, 実際には認知・判断できる状況に至っておらず, 介入要 求に応えるには不適切な状態である可能性が示唆される. この 「意識の脇見」に似た状態は，ドライバが，システムに介入し なければならない状態であっても，適切に対応できない可能性 を示唆していると考えられる。

\section{4. まとめ}

本論では，自動運転に対する過信・依存，および，システム 破綻を想定した後のドライバ状態を，ドライビングシミュレー 夕を用いた実験を通じて計測・解析した結果について述べた。 実験条件の設定などの難しさなどもあり，推測の域を超えない 内容もあるが, 本論で述べた実験と考察を通じ, 自動運転時の 過信・依存について, 十分とは言えないが, 一定の知見が得ら れたものと判断している.

筆者は決して自動運転それ自体を否定するつもりはない。自 動運転は QOL (Quality of Life), 利便性を向上させると共に, 今後の高齢化社会に向けて必要になる技術である。しかし, 同 時に, 自動運転に対しては, その利便性のみが誇張されており, やや美化, 礼賛され過ぎている感もある。重要なことは, 自動 運転技術の長所と短所をそれぞれ理解し, 過信しないようにす ることであると考えている，また，未だに，世間では，「運転 支援」と「自動運転」を混在させ, 誤解を招いている印象もあ 
る.このことが, 自動運転の長所と短所の理解の妨げになって いる一因でもある。そのためには，「システムはこの程度まで ならできる(この程度しかできない)」「システムは破綻する可 能性がある」「ドライバは自動運転に過信・依存する可能性が ある」ということを意識した上で，今後，どのように自動運転 と接するべきか，各々がしっかりと考えるべきである.

\section{謝辞}

本研究は, 科研費若手研究 (B)「自動運転のあるべき姿と は? -ドライバ負荷軽減と依存, システムダウン後の復元か らー」(課題番号：15K21486）の支援を受けた。

\section{参 考 文 献}

[1] 津川定之: “自動運転システムの展望,” ITASS Review, Vol.37, No.3, pp. 39-47, 2013.

[2] WIRED, 写真で見る「自動運転車の歴史」: http://wired.jp/2012/ 02/09/autonomous-vehicle-history/ [accessed Feb. 5, 2020]

[3] 須田義大, 青木啓二: “自動運転技術の開発動向と技術課題,”情 報管理, Vol.57, No.11, pp. 809-817, 2015

[4] 国土交通省自動車局技術政策課, 自動運転を巡る国内·国際動向: http://www.mlit.go.jp/common/001279905.pdf [accessed Feb. 5, 2020]

[5] 高度情報通信ネットワーク社会推進戦略本部・官民 データ活用推進戦略会議, 官民 ITS 構想・ロードマップ 2019: https://www.kantei.go.jp/jp/singi/it2/kettei/pdf/20190607/ siryou9.pdf [accessed Feb. 5, 2020]

[6] 高度情報通信ネットワーク社会推進戦略本部・官民 データ活用推進戦略会議, 官民 ITS 構想・ロードマップ 2017 〜多様な高度自動運転システムの社会実装に向け て〜: https://www.kantei.go.jp/jp/singi/it2/kettei/pdf/20170530/ roadmap.pdf [accessed Feb. 7, 2020]

[7] 劉海龍, 平岡敏洋, 田中誠也: “運転自動化システムに対する過信 発生メカニズムと運転行動過程のモデル化, ”計測自動制御学会 システム・情報部門学術講演会 2018 講演論文集, 2018.

[8] 増田貴之, 芳賀繁: “運転行動モデルと事故防止,”日本信頼性学 会誌, Vol.31, No.3, pp. 223-227, 2009.

[9] 稲垣敏之: “人と機械の共生のデザイン：「人間中心の自動化」を 探る,”森北出版, 2012.

[10] 厚生労働省, 依存症についてもっと知りたい方へ: https://www. mhlw.go.jp/stf/seisakunitsuite/bunya/0000149274.html [accessed Feb. 5, 2020]

[11] Dive into Myself, システムや機械の利用と依存: https: //diveintomyself.funfairfanfare.com/ [accessed Feb. 5, 2020]

[12] 金道敏樹: “自動車からの Human-Agent Interaction への期待,” HAI シンポジウム予稿集, 1D-4, 2012.

[13] ニュースイッチ, テスラの自動運転事故が浮き彫りにしたド ライバーの過信: https://newswitch.jp/p/12564 [accessed Apr. 4, 2020]

[14] 伊藤誠: “負荷軽減のための運転支援システムに対する過信を もたらす要因の探究,”計測自動制御学会論文集, Vol.45, No.11, pp. 555-561, 2009.

[15] 鈴木桂輔, 丸茂喜高: “システム依存を抑制する運転支援装置の 制御方法, ”日本機械学会論文集 C 編, Vol.70, No.699, pp. 32793285, 2004.

[16] T. Arakawa, N. Matsuo, and M. Kinoshita: "Trial Evaluation on Drivers' Unfocused Attention Using Gaze Analysis," Review of Automotive Engineering, Vol.27, No.2, pp. 357-359, 2006.

[17] 大谷亮, 江上嘉典, 佐藤健治, 三井一志, 阿部正明: “自動運転状況 下におけるドライバへの情報伝達方法一低中度の自動運転シス テムからの情報伝達が運転行動に及ぼす影響一,”自動車技術会 論文集, Vol.47, No.4, pp. 961-966, 2016.

[18] 産業科学技術研究開発プロジェクト「人間感覚計測応用技術」: 人間感覚計測マニュアル 第一編（人間感覚評価指標・ガイドラ
イン) , 1999.

[19] 中野泰彦, 宮川あゆ, 佐野聡: “ドライバの覚醒度検知技術,” FUJITSU, Vol.54, No.4, pp. 416-420, 2008.

[20] 本間亮平, 若杉貴史, 小高賢二: “高度自動運転における権限委 譲方法の基礎的検討一自動運転時の覚醒度低下や運転以外の作 業と権限移譲時のドライバ対応行動—, ”自動車技術会論文集, Vol.47, No.2, pp. 537-542, 2016.

[21] J. C. F. de Winter, R. Happee, M. H. Martens, and N. A. Stanton: "Effects of Adaptive Cruise Control and Highly Automated Driving on Workload and Situation Awareness: A Review of the Empirical Evidence," Transportation Research Part F: Traffic Psychology and Behavior, Vol.27, pp. 196-217, 2014.

[22] 国土交通省, 自動運転のレベル分けについて：http://www.mlit. go.jp/common/001226541.pdf [accessed Feb. 11, 2020]

[23] 向殿政男: 入門テキスト安全学, 東洋経済新報社, 2016 .

[24] BBC NEWS, Tesla in fatal California crash was on Autopilot: https://www.bbc.com/news/world-us-canada-43604440 [accessed Feb. 5, 2020]

[25]@nifty二ュース，車についてのアンケート・ランキン グ: http://chosa.nifty.com/travel/chosa_report_A20120824/5/ ?theme $=$ A20120824\&report $=5 \&$ theme $=A 20120824 \&$ report $=5$ [accessed Apr. 6, 2020]

[26] F. C. Baker and H. S. Driver: "Circadian rhythms, sleep, and the menstrual cycle,” Sleep Medicine, Vol.8, No.6, pp. 613-622, 2007.

[27] T. Arakawa, R. Hibi, and T. Fujishiro: "Psychophysical assessment of a driver's mental state in autonomous vehicles," Transportation Research Part A: Policy and Practice, Vol.124, pp. 587-610, 2019.

[28] 万井正人: “自動車運転中の連続血圧測定,”人間工学, Vol.3, No.1, pp. 45-52, 1967.

[29] 大見拓寛: “運転者の居眠り状態評価の画像センサ,”人工臓器, Vol.42, No.1, pp. 99-103, 2013.

[30] B. L. Seaward: Managing Stress: Principles and Strategies for Health and Well-Being, Jones \& Bartlett Learning, 2011.

[31] 内田信行, 浅野陽一, 横谷靖, 植田俊彦, 飯星明: “「意識の脇見」 を伴う対話時における運転者の視覚情報処理, ”自動車技術会論 文集, Vol.39, No.6, pp.6_217-6_222, 2008.

(2020 年 4 月 7 日 受付)

\section{[問い合わせ先]}

干443-0047 愛知県蒲郡市西迫町馬乗 50-2

愛知工科大学 工学部 機械システム工学科

荒川 俊也

E-mail: arakawa@arakawalab.org

著者 紹介

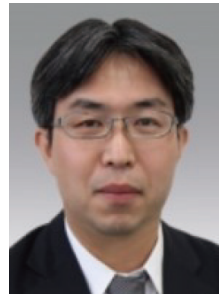

荒川剖俊也 [正会員

2001 年早稲田大学理工学部機械工学科卒業. 2003 年東京大学大学院総合文化研究科広域科 学専攻博士前期課程終了。2003-2013 年富士 重工業株式会社（現：株式会社 SUBARU）勤 務. 2012 年総合研究大学院大学複合科学研究 科統計科学専攻博士後期課程終了。2013 年愛 知工科大学工学部機械システム工学科准教授, 2016 年同大学同学部同学科教授. 2020 年同 大学次世代自動車システム研究所所長. 2017 年より政策研究大学院大学政策研究センター 客員研究員. 日本知能情報ファジィ学会, 自 動車技術会, 計測自動制御学会などの会員. 博士 (学術) 